IFN Working Paper No. 1143, 2016

\title{
Marketized Education: How Regulatory Failure Undermined the Swedish School System
}

Johan Wennström 


\title{
MARKETIZED EDUCATION: HOW REGULATORY FAILURE UNDERMINED THE SWEDISH SCHOOL SYSTEM
}

\author{
Johan Wennström*
}

October 2017

\begin{abstract}
In a radical school choice reform in 1992, Sweden's education system was opened to private competition from independent for-profit and non-profit schools funded by vouchers. Competition was expected to produce higher-quality education at lower cost, in both independent and public schools. This article analyzes whether the school choice reform was institutionally secured against school competition based on phenomena that are unrelated with educational quality. Interviews with senior policy makers reveal that the architects of the reform overemphasized the virtues of market reforms and therefore did not deem it necessary to establish appropriate rules and institutions for school competition. Instead, ill-conceived grading and curriculum reforms paved the way for moral hazard resulting in grade inflation and other forms of unintended school competition. The lesson from Sweden's experience is that market reforms of public services production, particularly those that introduce for-profit producers, must account for how institutions and incentive structures affect behavior.
\end{abstract}

\footnotetext{
* Department of Political Science, Linköping University, SE-581 83, Linköping, Sweden, and Research Institute of Industrial Economics (IFN), Box 55665, SE-102 15 Stockholm, Sweden. Email: johan.wennstrom@ifn.se. The author gratefully acknowledges financial support from Stiftelsen Millenium and thanks Magnus Henrekson, Johan Tralau, Elin Wihlborg, Gabriel Heller Sahlgren, Mårten Lindberg, Niclas Berggren and Dana D. Dyson for helpful suggestions. This article has also benefitted from comments received at MPSA 2016 in Chicago; Roskilde University, Denmark; and WINIR 2016 in Boston.
} 


\section{INTRODUCTION}

This article makes a novel contribution to the existing scholarship on Sweden's internationally recognized school choice system by (1) demonstrating the existence of competition-induced grade inflation in both independent schools and public schools and

(2) by using an institutional theory of markets to explain why school competition has resulted in increasing discrepancies between absolute test results and grades, i.e., grade inflation. It details the 1992 universal school voucher reform as well as other education reforms enacted simultaneously that effectively removed institutional safeguards against opportunistic behavior within the newly created school choice system at that time.

Ultimately, the article describes how the objective of raising the quality of education in Swedish schools through competition and choice was inadvertently undermined.

In contrast to this article, most previous internationally available studies on school competition in Sweden have concentrated on easily measured educational outcomes - i.e., teacher-assigned grades and the results of Swedish "standardized" tests, which are not kept hidden from students and teachers and are not graded externallyand found that the expansion of independent schools after 1992 has improved results in both independent and public schools. However, this literature has considered neither the striking discrepancies between Swedish grades and the results of objectively graded international knowledge assessments nor the fact that the lax institutional framework of the school choice system has allowed for grade inflation and other forms of unintended school competition from its inception. Thus, the previous literature says little about the quality of the education pupils are receiving in the school choice system. This article aims to investigate precisely this matter. Although the analysis focuses on the Swedish school choice system, the conclusions are also pertinent to general discussions about 
privatization of education and other areas of public sector responsibility in the U.S., the UK and other countries (e.g., Angulo, 2016).

The article consists of six sections. The remainder of this introduction discusses the background of the study, explains its methodology, and presents the main findings. Section two presents an overview of Sweden's education system and its school market. Section three sets out a detailed case for the existence of competition-induced grade inflation and surveys previous studies that are relevant to this discussion. Explaining the remaining findings of the article requires a discussion of the importance of welldesigned institutions to guaranteeing that markets function properly, which is undertaken in section four. The fifth section demonstrates how such theoretical insights were either unknown to or ignored by those policy makers who brought market principles into the Swedish education system in the early 1990s. The last section presents the conclusions.

Together with Chile's voucher system, the school choice reform that was introduced in Sweden in 1992 is unparalleled internationally in its liberal market design (Vlachos, 2012). It allows private actors such as foundations, parental cooperatives and for-profit firms to establish independent schools (friskolor) that operate on the same terms as public schools and are financed through a voucher scheme similar to that proposed by Milton Friedman more than 60 years ago (1955). ${ }^{1}$ Prior to this reform, there were few independent schools operating in Sweden, and over 98 percent of pupils attended their nearest public school. The reform was meant to encourage choice among pupils and competition among schools. Restrictions on independent schools were then as they are now - few and did not include competence requirements for owners, such as previous management experience from the educational sector, or any restrictions on the 
right to pay dividends to the owners of the schools or to sell the school under the same conditions as any other business.

Moderate Prime Minister Carl Bildt's center-right coalition government of 1991-1994, which implemented the reform, valued freedom of choice as an end in itself (Government bill, 1991/92:95). However, there were also expectations that the new element of competition would produce education of higher quality at lower cost in both independent and public schools (Government bill, 1991/92:95, p. 9). ${ }^{2}$ In an opinion piece launching the reform, the Moderate Minister of Schools Beatrice Ask (1992) wrote: "The independent schools have all the prerequisites to be the vitalizing force urgently needed in the public school system. New alternatives and new methods can be tried and contribute to the improvement and deepening of the level of knowledge among Swedish pupils, and confirm that schools remain strongholds of knowledge." This optimism was in line with Friedman's (1962/2002, p. 93) prediction that “the development and improvement of all schools would [...] be stimulated."

Ostensibly, these goals appear to have been achieved; recent studies on the effects of school competition on educational outcomes find that the expansion of independent schools has improved outcomes in both independent and public schools. However, concerns have also been expressed over the reliability of grades and Swedish standardized tests as indicators of the quality of education. In fact, one of this study's main findings is that such concerns are warranted; while a dramatic rise in grades has occurred over the last fifteen years, that rise is not matched by higher results of international tests of pupils' knowledge and adult cognitive skills. On the contrary, the results of Swedish pupils have dropped sharply both absolutely and relative to the OECD average. Hence, the evidence of grade inflation is quite strong, and it may in fact 
be caused by school competition. How did this occur despite the reformers' good intentions?

Grade inflation can be considered a negative externality in terms of basic human interests (Claassen, 2016), as it has detrimental effects on knowledge acquisition, ${ }^{3}$ which is one of the basic goods that individuals require to lead flourishing lives. Negative externalities are in turn the result of institutional failure (Frank, 2012; Ostrom, 1990). While institutional arrangements can lead to hazardous behavior, such "hazardous adjustments come with a lag and do not occur immediately", according to Eggertsson (2005, p. 149), drawing on Lindbeck (1995). Therefore, educational institutions established in conjunction with the school choice reform must be examined; in addition, the incentives created regarding grade setting in general and those related to school competition in particular must also be investigated. This is all the more pertinent as the changes to the education system that were made in the early 1990 s were intended to be aligned and integrated (Ask, 1992).

In conducting this study, I draw on primary sources, such as government bills, documents from the Swedish National Agency for Education, and newspaper articles; published research; and interviews with two senior policy makers behind the 1992 universal school voucher reform, Odd Eiken and Anders Hultin. Thus, I make use of two of the main tools for qualitative policy studies: document analysis and interviews (Gibton, 2016). The interviews were conducted by email (Eiken) and by telephone (Hultin), which, although not ideal, is not uncommon in the context of interviewing senior policy makers (Gibton, 2016). Hence, no recordings were made, but the telephone interview was documented in writing. The main purpose of the interviews 
was to gain insight into the reasoning of the architects of the reform at the time of its introduction.

Although a more comprehensive study is necessary to firmly establish causality, the article provides a tentative yet plausible hypothesis regarding the emergence of competition-induced grade inflation. I find that the school choice reform was not adequately secured against certain negative externalities of the nature discussed above. Inspired by Milton and Rose Friedman's proposal for a voucher program (1980), the architects of the reform in the liberal-conservative Moderate Party, which was in charge of education policy in the center-right coalition government of 1991-1994, placed too much faith in the free market's ability to produce education of a higher quality at a lower cost irrespective of the regulatory framework. Establishing appropriate rules and institutions for school competition was deemed unnecessary because policy makers assumed that private actors under any circumstances would produce better and more cost-efficient educational services. They instead enacted reforms to grading and the curriculum that made it institutionally possible for independent schools - and eventually also public schools - to compete in dimensions other than educational quality. The mechanisms are similar to those that gave rise to the financial crisis of 2008 in which regulatory failure paved the way for moral hazard and made it rational for banks to compete by lowering lending standards. Part of the responsibility also falls on the political Left. The Social Democrats were advocates for and participated in the grading and curriculum reforms. Despite twelve years in government, 1994-2006, they took no major steps toward reforming the system and improving its functionality. 
Sweden's educational system is divided into compulsory primary education (grades 1-9) and voluntary secondary education. Most children begin compulsory school at the age of seven, some at the age of six, and they finish at the age of sixteen. Most pupils then enter the secondary education system and finish at the age of nineteen. ${ }^{4}$ Academic grades determine whether pupils will be admitted to the secondary school of their choice and into a university after they leave secondary school. However, despite the importance grades have regarding future success, "the Swedish school system is unique when leaving the entire responsibility for the grading to the schools, and consequently to the teachers" (Wikström and Wikström, 2005, p. 310).

Both compulsory primary education and voluntary secondary education are the responsibility of the municipalities as the result of a decentralization reform enacted by the Social Democrats in 1991 and fully developed in the mid-1990s by the center-right coalition government. Municipal tax revenues and general government grants are their main sources of finance. The role of the central government is merely to set goals and objectives for education through the Swedish National Agency for Education (established in 1991) and to ensure that schools are complying with relevant legislation through the Swedish School Inspectorate (established in 2008). Prior to the decentralization reform of the early 1990s, the education system was heavily regulated perhaps more than any other public institution in the world (Lewin, 2014, p. 57).

With the exception of a few independent schools, which essentially taught the children of the wealthiest families or had alternative pedagogic profiles and were only partially supported by funds from the state, the comprehensive public school dominated the education sector in Sweden from the 1970s until the implementation of the school choice reform in $1992 .{ }^{5}$ The independent schools then received funding through a 
voucher system of a minimum of 85 percent of the average cost per pupil in public schools - raised to 100 percent in 1997 in exchange for independent schools abandoning limited student fees, which were originally allowed (Government bill, 1995/96:200). And through a change in the legislation, it also became possible for pupils to choose a school - either public or private — other than the nearest one in proximity to their homes. These changes broke up the government's near-monopoly on education and paved the way for competition among schools. The only restriction on independent schools was that they had to abstain from "cherry picking" pupils based on ability or socio-economic background. Since 2010, they have also been explicitly required to follow the national curriculum (Swedish law, 2010:800).

The first year after the reform was enacted, the number of independent schools doubled, and during the next decade a new education market emerged at both primary and secondary levels. In the academic year 2014/15, 14 percent of pupils in primary education attended any one of the 800 independent schools at this level, and 26 percent of pupils in secondary education attended any one of the over 450 independent secondary schools that now exist in Sweden (Edmark, 2015).

Contrary to what many seem to have believed at the onset of the reform, ${ }^{6}$ the education market has become progressively more professionalized. Most independent schools do not offer an alternative pedagogy, but have a general profile that competes directly with the public schools. For-profit firms constitute 60 percent of all independent primary schools and 86 percent of all independent secondary schools (Edmark, 2015). Increasingly, independent schools are concentrated to large business groups. For example, in the school year 2014/15, the leading firm in the education sector, Academedia, enrolled approximately 3.5 percent of all pupils in primary and secondary 
education in any one of its wholly-owned but differently branded schools (Academedia, 2015). This is not dissimilar to how leading consumer companies win market shares for consumer goods through their many different brands. Indeed, the parallel is quite apt. For although this education market is a "quasi market" (Le Grand and Bartlett, 1993), there is evidence that is behaves much like a regular market, adjusting to consumer demand regardless of whether this improves the quality of education.

\section{EVIDENCE OF GRADE INFLATION}

In the PISA 2012 international education survey, which assesses the knowledge of fifteen-year-old pupils, ${ }^{7}$ Sweden scored below average among OECD countries in reading, mathematics and science (OECD, 2013b). Likewise, in TIMSS 2011, which assesses the mathematics and science knowledge of $4^{\text {th }}$ and $8^{\text {th }}$ graders, even pupils of the heavily criticized American education system ${ }^{8}$ achieved better results than Swedish pupils in mathematics in $8^{\text {th }}$ grade at all student achievement levels (Mullis et al., 2012). ${ }^{9}$ This represented the lowest point in a long decline of Sweden's results in international standardized tests (Hanushek et al., 2012). ${ }^{10}$ However, since the mid1990s, grades have continually risen in both primary and secondary schools in Sweden, as has the share of pupils who receive the highest grade (Holmlund et al., 2014; Vlachos, 2010).

\section{[Insert table 1 about here]}

These opposing trends become strikingly evident from the OECD's country report on education in Sweden (OECD, 2015) and in one of its graphs reproduced here (Fig. 1). This figure shows both the development of the average merit rating in year 9 
(the final year of primary education) and the PISA assessment data between the academic years 1997/98-2011/12. According to the Swedish National Agency for Education (2014), international standardized tests such as PISA give an accurate picture of the level of knowledge among Swedish pupils and closely resemble the national curriculum. While merit ratings have improved during these years, Swedish pupils have steadily deteriorated in all three areas of PISA — reading, mathematics and sciencesince the tests began in 2000. This contradiction - that grades have markedly improved in Sweden while the level of knowledge as measured by valid international tests has declined — suggests that grades do not reliably measure pupils' knowledge and cannot be used as a valid indicator of the quality of education. ${ }^{11}$

[Insert figure 1 about here]

In the past, poor levels of substantive knowledge among Swedish pupils have often been excused by arguing that it was offset by the fact that pupils performed strongly in other important skills that are also weighed into grades, such as critical thinking and creativity. However, another recent PISA assessment has also revealed shortcomings (below the OECD average) in critical thinking, creativity, curiosity and perseverance (OECD, 2013a). Sweden was ranked $20^{\text {th }}$ out of 28 countries when the test was given in 2012. Assertions that the improvement in grades reflects the strengthening of such skills — independent of the level of knowledge — can therefore be rejected.

Hence, neither the external tests of knowledge level nor the PISA assessment about problem-solving skills can explain the sharp increase in grades. Perhaps the most puzzling fact is that the share of Swedish pupils who receive the top grades has increased dramatically and that the same group is also performing worse on international tests, particularly in mathematics (Mullis et al., 2012). The combination of 
rising grades and declining international test scores thus suggests grade inflation (Holmlund et al., 2014). ${ }^{12}$

Yet another indicator of grade inflation is Sweden's decline in PIAAC, ${ }^{13}$ which assesses adult cognitive skills in literacy, numeracy and problem-solving ability. Sweden's deteriorating results in PISA are perfectly mirrored in the same age cohorts in PIACC, which reveals that poor results at age fifteen "remain unchanged at least twelve years after primary education” (Löfbom and Sonnerby, 2015, p. 71). Because school competition in Sweden has raised educational outcomes in both independent and public schools, and given that this might be explained by grade inflation, it follows that grade inflation might be an unexpected and undesired consequence of the school choice reform and its voucher system.

The voucher reform has given schools an economic incentive to compete for pupils. However, the regulatory framework offers independent schools no particular incentive to compete based on quality of education rather than in terms of how grades are assigned, and other material and immaterial rewards, such as free driving instructions and personal computers (which are commonly offered to pupils), ${ }^{14}$ or other enjoyable frills. This grading competition is made possible, at least in principle, by the fact that teachers themselves (and not independent external examiners) assign grades in Sweden. Additionally, in the quasi market that education has become, charging higher fees to provide a better service is not possible; hence, profitability can be boosted only by attracting more pupils. The fact that parents and pupils are generally satisfied with independent schools (Svenskt Kvalitetsindex, 2015), even though those schools took the lead early on in offering inflated grades, which is demonstrated by a study of competition among Swedish secondary schools in 1997 (Wikström and Wikström, 
2005), ${ }^{15}$ may suggest that a preference for high grades and low effort has emerged. Changing social norms concerning the value of education might have strengthened such a preference because the appreciation for education tends to decrease in wealthy and highly modernized societies (Heller Sahlgren, 2015). The market setting itself may have created a "moral disengagement" and reduced the salience of fairness in the minds of parents and pupils, as suggested by powerful experiments conducted in economics that revealed the corrosive effect of markets on ethical reasoning (Bowles, 2016). Taken together, these factors would make it rational for schools, even public schools, not to compete by offering an education of high standards in a "Darwinian market process" (Frank, 2012).

That such a mechanism is likely has been shown by Vlachos (2010) in a study of the effect of school competition on grade inflation (measured in a different way). ${ }^{16}$ While that effect is small, the true impact of school competition on grade inflation is likely to be underestimated, according to the author. ${ }^{17} 18$ One important reason for this underestimation is that the grades are not compared to an objective and time-invariant measure of the level of knowledge (Vlachos, 2010, p. 47). Swedish standardized tests are also graded too generously by teachers in both primary and secondary education, particularly in independent schools (Tyrefors Hinnerich and Vlachos, 2013; 2016). Therefore, Swedish standardized tests cannot be used as a standard against which grades can be gauged.

By contrast, international assessments offer this type of objective measure of knowledge. Therefore, in principle, the effect of school competition on grade inflation could be studied by examining the difference between grades and Sweden's performance on PISA and TIMSS. However, the fact that matching PISA data with 
schools and municipalities is not allowed has impeded the possibility of performing such an analysis. For the time being, we therefore must rely on the available evidence, which is quite strong. A study of the Norwegian education system, which has many similarities to the Swedish system, is also relevant in this context, as it found that grading practices are correlated with the number of schools in the municipality and that stringent grading is less likely to occur in competitive environments with credible exit options (Bonnesrönning, 2004a).

Until now, this section has presented evidence for the existence of competitioninduced grade inflation in Sweden's schools. Although none of the findings discussed are original to this article, the collection of findings provides a more comprehensive perspective on Sweden's school choice system than the previous literature on school competition offers. I will next turn to this literature.

One of the first major quantitative studies in this field was Sandström and Bergström (2005) who studied grades and performance on Swedish standardized tests in a sample of public school pupils at the primary level in the academic year 1997/98. This study found that "the extent of competition from independent schools [...] improves both the scores on a national standardized mathematics test and the grades in public schools" (Sandström and Bergström, 2005, p. 355). When including both public and independent school pupils at the primary level in the same year, Ahlin (2003) reported a similar significant effect of school competition on standardized test scores in mathematics. Björklund et al. (2004) found a positive impact on standardized test scores and final grades in Swedish, English and mathematics for the time period 1998-2000.

The largest and most recent quantitative study of school competition after the school choice reform in 1992 is Böhlmark and Lindahl (2015). These authors studied 
whether the share of independent school pupils at the municipality level affects educational outcomes for pupils in both public and independent schools. By examining grades, Swedish standardized test scores, and certain long-term outcomes among compulsory school graduates in 1988-2009, the authors found that an increase in the share of independent school pupils "improves average education performance both at the end of compulsory school and, in the long run, in terms of [secondary school] grades, university attendance and years of schooling" (Böhlmark and Lindahl, 2015, p. 542). The authors also analyzed cross-sectional TIMSS data on $8^{\text {th }}$ grade students in the years 1995, 2003 and 2007. They found that the general decline in test results over those years is somewhat smaller in municipalities with a higher share of independent school pupils.

Although the results seem promising, their significance is uncertain and they should therefore be interpreted with caution. Independent schools have truly raised educational outcomes in terms of grades and test results, but whether this is the equivalent of more knowledgeable pupils is less certain. Grades are not a reliable measure of the level of knowledge. Ahlin (2003) acknowledged this and therefore studied Swedish standardized tests instead, but as we have observed, these tests are also not reliable because they are graded by the pupils' own teachers.

Even the significance of the most promising study thus far, Böhlmark and Lindahl (2015), is difficult to assess. For example, these authors find no evidence of grade inflation, but as mentioned above, two different grading systems were in operation during their period of study - one cohort-referenced and one criterionreferenced. Additionally, how do we reconcile their premise that Swedish standardized tests can be used as a standard against which grades can be measured with the research 
showing that schools — and particularly independent schools - grade these standardized tests too generously (Tyrefors Hinnerich and Vlachos, 2013; 2016)? Moreover, how significant is Böhlmark and Lindahl's finding that a positive impact of school competition exists both on grades in secondary education and on university attendance when considering that grades in secondary education are possibly more inflated than grades in primary education (Vlachos, 2010) and that those grades are the most important selection criterion for university admittance $?^{19}$

Perhaps the authors' most notable result is their analysis of cross-sectional TIMSS data, but this is also difficult to evaluate. The authors demonstrate that municipalities with low and high shares of independent school pupils seem to run parallel in TIMSS between the years 1995 and 2003. However, between 2003 and 2007, the decline becomes less pronounced in municipalities with a high share of independent school pupils compared to those with a low share. As Böhlmark and Lindahl (2015, p. 509) themselves explained, test results "deteriorated less" in regions with a higher proportion of independent school students. When controlling for the number of books at home among the test-takers as well as the average socioeconomic composition in the municipality, this amounts to an increase of approximately 7 points, which corresponds to approximately 10 percent of a standard deviation (one standard deviation on the 2007 TIMSS test score is approximately equal to 71 points, according to the authors). This can hardly be considered a major positive effect of school competition on knowledge attainment.

I argue that all these studies illustrate that we need to widen the scope of research from grades and test scores to the institutional framework of the education 
system and the incentives it has created, particularly in combination with school competition. The remainder of this article will consider this issue.

\section{MARKETS AND INSTITUTIONS}

Markets require institutions to function as intended. Douglass North famously defined institutions as "the rules of the game in society or [...] the humanly devised constraints that shape human interaction" (North, 1990, p. 3). More recently, Geoffrey Hodgson (2006, p. 7) has expanded the definition of institutions to encompass durable social structures that serve not only as constraints but also as enablers of behavior with the "capacity to change aspirations" of agents. Economists, particularly those of the institutional economics school, have argued that markets cannot and should not be left alone but require appropriately designed institutions to function efficiently (Hodgson, 2013; Nooteboom, 2014). Since institutions shape moral habits (Ratnapala, 2006), they are needed to limit the negative effects that markets may have, such as the "crowding out" of intrinsic, non-material values and moral conduct from areas in which markets are allowed to operate (see, e.g., Bowles, 2016; Sandel, 2012) and to make markets work as well as they can.

Since markets are fundamentally about satisfying demand, whatever that might be to the individual consumer who has limited rationality and is frequently swayed by short-term considerations, it is not self-evident that markets serve collective aims (Nooteboom, 2014). Hence, institutions must restrain markets and freedom of choice to some extent, as stipulated by North's definition (1990). A lack of appropriate, constraining institutions may ultimately lead to moral hazard (Kasper et al., 2013). The broader view of institutions as also having the capacity to change the aspirations of agents, as suggested by Hodgson (2006), brings another important point to light. 
Prisoners' dilemma-type situations in which agents such as firms think they cannot afford to take less self-interested courses of action, as others will not go along, is a wellknown problem of markets and can have detrimental effects on society at large (Nooteboom, 2014). In these situations, appropriate institutions may support socially concerned actors and shift competition towards outcomes that are more desirable from a public perspective.

Institutions must be carefully designed, particularly in conjunction with privatization and in cases in which markets become providers of publicly financed services, such as education (Hodgson, 2013; Nooteboom, 2014). Principals then must examine whether regulatory frameworks and incentives are designed to encourage moral behavior among agents. Voucher reforms, for example, would most appropriately entail institutions that both limit moral hazard and favor those schools that wish to compete in educational quality and not in other dimensions. Milton Friedman (1955) suggested such a framework in his original proposal for a voucher reform program more than 60 years ago when calling for a basic core curriculum, set by the state to ensure homogenous performance standards and administered in privately run schools as well. Another appropriate regulation is the external assignment of grades, as suggested by studies showing that teacher cheating is sensitive to incentives and that the presence of external examiners reduces cheating by teachers and students. ${ }^{20}$ However, as will be shown, such institutions were either absent or undermined in the Swedish case.

We can gain help in understanding the importance of institutions, from a strand of literature on the financial crisis of 2008 that is linked to these perspectives, such as Richard Posner's book A Failure of Capitalism (2009) and Raghuram Rajan's book Fault Lines (2010). Both authors argue that the financial crisis cannot be blamed on 
either markets or the government alone, but that it was a "systemic" crisis caused largely by hazardous incentives and a lack of appropriate regulation.

Posner argues that the period from the 1970s onward could be considered a "deregulation movement" of profound range within the U.S. financial industry, which dissolved boundaries between traditional banks and new, competitive financial intermediaries such as hedge funds and lifted regulatory restrictions on risky lending. This movement intersected with falling interest rates in the early 2000s and the appetite for increased refinancing of existing house mortgages among lenders "with little thought for the future", who often could not afford to service their loans (Rajan, 2010, p. 129). Banks, according to both Posner and Rajan, behaved rationally from their point of view and in line with the market principle of satisfying demand when they began competing by lowering lending standards. "Businessmen can no more afford to consider the effect of their decisions on the economy as a whole than consumers can", Posner observes (2009, p. 325). Government regulators should have restricted this risky form of competition on the lending market, but instead, they trusted that markets would be self-regulating (Posner, 2009). This left the financial system vulnerable when a housing bubble eventually burst and lenders defaulted on their mortgages, which in turn caused the banks to fail. As will be shown in the next section of this article, similar mechanisms have been at work in the Swedish education system.

\section{A FAILURE OF INSTITUTIONS}

In 1991, one year before Carl Bildt's center-right government implemented the school choice reform, Sweden's education system was decentralized and deregulated by a Social-Democratic government. The reform reduced the role of the central government in education to merely setting general goals and objectives and placed 
primary and secondary schooling under the full responsibility of the municipalities (Government bill, 1990/91:18). ${ }^{21}$ One reason for this reform was the trend of decentralization and management by objectives that swept through public administration in Sweden during the 1980s (Lewin, 2014), but it was also congruent with a movement to reduce government regulation in education that had been developing since the 1970s (Haldén, 1997). Both the political Left and the political Right had attributed the shortcomings of the comprehensive public school system to detailed regulation of the scope and content of education. They had argued that the quality of schools would improve if they were decentralized to local authorities and given greater freedom to pursue their own approaches (Ringarp, 2011).

The decentralization reform of 1991 reflected these political convictions. The Social-Democratic Minister of Education at the time, Göran Persson (Prime Minister 1996-2006), vowed to reduce the size of the school regulatory system and swiftly abolished the National Board of Education (established in 1920), which was viewed as an obstacle to the realization of a new, deregulated and decentralized education system (Haldén, 1997). In its place, a new body was established: the National Agency for Education. However, it was not primarily a regulatory agency. In fact, the National Agency for Education defined itself in opposition to the abolished National Board of Education and pledged to "dismantle traditional supervision and control" (Haldén, 1997, p. 17). Its first Director-General expressed a direct disregard for the institutional memory of the previous organization and publicly voiced fears that that its "bureaucracy was stuck to the walls" of the newly created agency (Kornhall, 2013, p. $51)$. 
The primary task of the National Agency for Education was not to directly regulate schools but to collect information and perform analyses. It was believed that the agency's research into "good examples" of successful schools would inspire other schools to improve themselves and that this would ultimately function as an indirect form of regulation (Haldén, 1997). However, it can be argued that in effect, this amounted to a policy of self-regulation of schools. It was thus into this debilitated institutional setting that the independent schools were introduced only one year later when the school choice reform was enacted in 1992.

Ideas for a school choice reform based on vouchers had first emerged in the youth league of the Moderate Party in the 1970s. However, until the beginning of the 1980s, "the Young Moderates were fairly alone in having these ideas, also in relation to the policies of the mother party", according to Odd Eiken (email, 12 January, 2014), State Secretary in the Department of Education 1991-1994 and one of the prime architects of the school choice reform. During the second half of the 1980s, school choice and vouchers successively became a more popular issue to adopt, both within the mother party and outside of it by free market organizations such as the influential freemarket think tank Timbro. An ideological movement for greater individual freedom and less government intervention was growing inside the Moderate Party (Reinfeldt, 2015, p. 60). A general discussion throughout society, even in the Social-Democratic Party, about the shortcomings of the public sector was also taking place. It noted the shortfalls in delivering welfare services of high quality and the need for private alternatives, which gave impetus to school choice as well as other ideas to reform public monopolies in the provision of education, healthcare, childcare, and elderly care (Jordahl and Öhrvall, 2013). By the election of 1985, the Moderate Party had developed a plan to 
implement a school choice reform if elected to power (Odd Eiken, email, 12 January, 2014).

The Moderate Party's main source of inspiration for the reform that eventually came into effect in 1992 — according to both Odd Eiken (email, 12 January, 2014) and Anders Hultin, political adviser in the Department of Education 1991-1994 (telephone interview, 11 February, 2014)—was Milton Friedman's voucher scheme, as presented in his book with Rose Friedman, Free to Choose (1980). Based on their experience in the U.S., the Friedmans were critical of government monopolies in education and argued that publicly run schools serve the interests of teachers and administrators rather than those of parents and pupils, who have to conform to the bureaucracy's goals. To counter this transfer of power from "consumers" to "producers" in education, the Friedmans proposed giving vouchers to pupils and thus the freedom to choose among schools, including those that are privately run.

This would open a vast education market in which "only those schools that satisfy their customers will survive - just as only those restaurants and bars that satisfy their customers survive" (Friedman and Friedman, 1980, p. 205). The comparison with restaurants and bars may sound hedonistic. However, a voucher plan would "bring learning back into the classroom", according to the authors, "since parents have greater interest in their children's schooling [...] than anyone else" (Friedman and Friedman, 1980, p. 194). The Friedmans clearly intended public and independent schools to compete in educational quality and not in other dimensions. Indeed, they argued that, "as the private market took over, the quality of all schooling would rise so much that even the worst, while it might be relatively lower on the scale, would be better in absolute quality" (Friedman and Friedman, 1980, p. 206; emphasis in original). 
According to Anders Hultin (telephone interview, 11 February, 2014), the architects of Sweden's school choice reform shared this "naïve view" of private actors" ability to improve educational quality. "There was an instant air of quality about the private sector when compared to the public sector."

This overconfidence in the market caused the center-right government to make regulatory mistakes when implementing the school choice reform. Here, I will point to two principal weaknesses. First, the architects of the reform overlooked Milton Friedman's crucial point about enacting a basic core curriculum to ensure homogenous performance standards (Friedman, 1955) — perhaps because this point was not included in the proposal in Free to Choose (Friedman and Friedman, 1980). Indeed, it was not until 2010 that independent schools were explicitly made to follow the national curriculum; at first, they were only required to follow "a curriculum" approved by the National Agency for Education (Government bill, 1991/92:95, p. 11), and then, after 1997, a curriculum that essentially corresponded to the national curriculum (Government bill, 1995/96:200). Second, the grading system was changed to give teachers greater flexibility and autonomy in awarding grades.

In conjunction with the school choice reform, the government enacted a curriculum that was considerably less prescriptive than the previous one and that lacked clear instructions regarding the scope and content of education (Swedish National Agency for Education, 1994). However, this was in line with the spirit of the new, deregulated school system in which the government would only set general goals and objectives. It was also congruent with the views of the Moderate Party's Minister of Schools, Beatrice Ask, who had previously argued for "less central management of content in schools" (Ask, 1990, p. 367). 
The new national curriculum stipulated that what was to be taught would be determined at the local level, in local curricula, in actual fact: "It is really only in the individual school that one can talk about a curriculum in the true sense of the word", according to the National Agency for Education at the time (1996, p. 22). The responsibility for learning was largely transferred to the pupils themselves, who were expected to be involved in the planning of lessons and discussions about the content of their education. This transfer of responsibility to the pupils had been prepared by the previous Social-Democratic government whose Minister of Education, Göran Persson, had guaranteed "pupil influence" in the law and argued that the education system could and should instill democratic values in pupils by applying "democratic" and not “authoritarian" forms of education (Government bill, 1990/91:115, p. 53). Having no objections, the center-right government carried out the policy and implemented it in the new curriculum. To Beatrice Ask, who is most aptly characterized as a liberalconservative, giving pupils greater influence over their education was a matter of individual freedom (Svenska Dagbladet, 1993b).

Moreover, the traditional concept of knowledge in education was marginalized or even eliminated in the new curriculum. Training in diligence, perseverance and other non-cognitive skills, which facilitate the attainment of knowledge (e.g., Heckman and Rubenstein, 2001) and which were emphasized in the previous curricula, was consequently abandoned (Hörnqvist, 2012). The official commentary on the curriculum explained the new definition of knowledge: "knowledge is seen as an expression of man's (the pupil's) relationship with the world rather than something 'in itself' to be 'attained"' (Swedish National Agency for Education, 1996, p. 9). The soft curriculum effectively left it to the individual schools to decide on the importance of teaching 
traditional knowledge. The radical decline in knowledge in the PISA surveys is most pronounced among pupils who were educated in accordance with this curriculum (Henrekson and Jävervall, 2016), and this fact suggests that "traditional" knowledge was not prioritized.

Taken together, the changes to the curriculum meant that there was no longer a basic core of knowledge that all pupils were expected to master and which could have prevented school competition from undermining the quality of education. Intriguingly, this was partly intentional. As was explained in an editorial at the time in the moderate newspaper Svenska Dagbladet (Hellman, 1993), the freedom given to schools to determine the content of education for themselves would also force public schools to develop different educational profiles and strengthen competition with independent schools. The National Agency for Education drew the same conclusion (Svenska Dagbladet, 1994b).

In conjunction with the school choice reform, the government also introduced a new absolute objective-based grading system (Gustafsson, 2012). In the previous relative grading system, teachers were required to justify in writing why they wanted to assign grades that greatly diverged from the result of standardized tests (Swedish National Agency for Education, 2005). The new grading system eliminated the authority of such standardized tests and gave individual teachers full autonomy to assign grades. The National Agency for Education realized that the grading reform would open the possibility of more ambiguous ("qualitative" according to the official term) evaluations of pupils' knowledge (Swedish National Agency for Education, 1996), and they welcomed this change. 
According to the National Agency for Education, the old grading system had been "characterized by the belief that it is possible to objectively measure knowledge". However, "ideas about the scientifically based and the 'objective"” and the idea that all pupils are "expected to learn the same things" were not in harmony with the new, objective-based education system (Swedish National Agency for Education, 1996, p. 35). What was now needed was a "re-thinking when it comes to assigning grades and what grades are but also the meaning of the terms fairness, comparability and equivalence". The agency concluded that "taken together, the orientation towards local variations, individual diversity and qualitative dimensions of knowledge require a different way of looking at assessments and grades" (Swedish National Agency for Education, 1996, p. 36). For example, it was deemed theoretically possible for a teacher to assign grades in any subject based on observations of the pupil that the teacher had made in circumstances other than the lesson in class.

The soft national curriculum and the deregulated grading system, both influenced by the belief that knowledge is a fluid concept, offered little institutional resistance to grade inflation and school competition in dimensions other than educational quality. However, according to both Beatrice Ask (1992) and the editorial page of Svenska Dagbladet (1993a; 1994a), the curriculum and grading reforms went hand in hand with the school choice reform, but with the tacit assumption that competition would only be based on educational quality.

Emblematic of this assumption is the fact that the center-right government "never considered external examination of grades" according to Anders Hultin (telephone interview, 11 February, 2014). “The pupil's right to choose was the central part of the reform", he says. Other aspects of the regulation of the independent schools 
had also not been thought through, despite the fact that Beatrice Ask (1992) had promised "strict quality control" of the schools. "The National Agency for Education was given the task of supervising independent schools, which was something entirely new to them and their first supervisory report was deplorable", according to Anders Hultin. "There was no competence or readiness for this", he says. This is perhaps not surprising given that the National Agency for Education did not consider itself to be a regulatory body (Haldén, 1997). Instead, market liberal ambitions intersected with the post-modern view of knowledge, which was influential in the National Agency for Education (Kornhall, 2013). While the free-market Right pressed for an objective-based grading system to make grades more comparable between schools and hence facilitate competition (Svenska Dagbladet, 1994a), the National Agency for Education considered grading reform to be an opportunity to dismantle the notion that it is possible to objectively measure knowledge.

This missing institutional framework could potentially have been rectified when the Social Democrats returned to governing in 1994. However, it was the Social Democrats who had decentralized the education system and abolished the National Board of Education. Accordingly, they had now also embraced the school choice reform and believed that competition between public schools and independent schools would improve the quality of education (Government bill, 1995/96:200, p. 37). To improve conditions for independent schools, the Social-Democratic government raised the vouchers to the full average cost per pupil in public schools.

The Social Democrats also supported the new grading system, but they made a significant reform vis-à-vis the policy of the previous center-right government. The Moderate Party wanted grades in at least six levels beginning at the latest in grade 7. 
This would not only serve as a tool for selection into higher levels of education but also as a motivational incentive to promote diligence and hard work. When the Social Democrats returned to power in 1994 (which they would hold until 2006), they reversed this policy. In contrast to the Moderate Party, the Social Democrats did not believe that grades provided incentives for learning. Therefore, grades were introduced from grade 8 and the grading scale was made less nuanced with fewer (only three) steps to ensure that grades became a tool for selection into higher levels of education and nothing else (Gustafsson, 2012). This resulted in the moral aspect of education being substantially attenuated and grades being reduced to a sort of currency, the main purpose of which was competition with others, which likely also played a part in creating a preference for inflated grades among parents and pupils.

\section{CONCLUSIONS}

Sweden's school choice reform, which together with Chile's voucher system is unparalleled internationally in its liberal market design, does not seem to have met the high expectations of its architects, i.e., that it would produce education of higher quality in both independent and public schools. The results from the only study that uses a convincing measure of quality, i.e., TIMSS (Böhlmark and Lindahl, 2015), are not impressive. The results of Swedish pupils in international knowledge achievement tests have declined, while domestic grades have increased. This suggests that (among other contributing reasons for the deterioration of knowledge) school competition is taking place in other dimensions than educational quality, including grading and other material and hedonic rewards.

This hazardous behavior is facilitated by regulatory failure. Because of overconfidence in markets, the center-right government that enacted the school choice 
reform in 1992 did not deem it necessary to appropriately regulate school competition. Through ill-conceived grading and curriculum reforms, the government instead paved the way for moral hazard. The succeeding Social-Democratic government did not take any major steps to reform the system to improve its functionality and thus protect basic social interests.

This analysis, which has pointed out faults in the implementation of Sweden's school choice reform, should not be seen as an implicit defense of school vouchers that are implemented in a rational and predictable manner. The normative issue of whether markets should be applied to education falls outside the scope of the article. The most important general lesson from Sweden's experience is instead that market reforms of tax-financed service production must account for the manner in which institutions and incentive structures affect behavior. This article has studied education, but there are also other (quasi) markets for tax-financed welfare services that are characterized by similar institutional weaknesses, triggering welfare-reducing adjustments of behavior, which can be studied and offer lessons. 


\section{REFERENCES}

Academedia. (2015), Årsredovisning 2014/15.

Aftonbladet. (2007), 'Skolorna slåss om gymnasieeleverna', 24 October. Available at: http://www.aftonbladet.se/nyheter/article11278805.ab.

Ahlin, A. (2003), Does School Competition Matter? Effects of a Large-Scale School Choice Reform on Student Performance, Working Paper, Uppsala: Uppsala University.

Angulo, A. J. (2016), Diploma Mills: How For-Profit Colleges Stiffed Students, Taxpayers, and the American Dream, Baltimore, Md: Johns Hopkins University Press.

Ask, B. (1990), 'Tankeväckande om skolan', Svensk Tidskrift, (6): 367.

Ask, B. (1992), 'Hård kvalitetskontroll på friskolor', Svenska Dagbladet, 5 April.

Bertoni, M., Brunello, G. and Rocco, L. (2013), 'When the Cat Is Near, the Mice Won't Play: The Effect of External Examiners in Italian Schools', Journal of Public Economics, 104(August): 65-77.

Betts, J. and Grogger, J. (2003), 'The Impact of Grading Standards on Student Achievement, Educational Attainment, and Entry-Level Earnings', Economics of Education Review, 22(4): 343-352.

Björklund, A., Edin, P.-A., Fredriksson, P. and Krueger, A. (2004), Education, Equality and Efficiency - An Analysis of Swedish School Reforms During the 1990s, Stockholm: IFAU.

Bonnesrönning, H. (2004a), 'Can Effective Teacher Behavior Be Identified?', Economics of Education Review, 23(3): 237-247.

Bonnesrönning, H. (2004b), 'Do the Teachers' Grading Practices Affect Student Achievement?', Education Economics, 12(2): 151-167.

Borcan, O., Lindahl, M. and Mitrut, A. (2014), 'The Impact of an Unexpected Wage Cut on Corruption: Evidence from a "Xeroxed" Exam', Journal of Public Economics, 120(December): 32-47.

Bowles, S. (2016), The Moral Economy: Why Good Incentives Are No Substitute for Good Citizens, New Haven, Conn: Yale University Press.

Böhlmark, A. and Lindahl, M. (2015), 'Independent Schools and Long-run Educational Outcomes: Evidence from Sweden's Large-scale Voucher Reform', Economica, 82(327): 508-551.

Claassen, R. (2016), 'Externalities as a Basis for Regulation: A Philosophical View', Journal of Institutional Economics, February 2016: 1-23.

Edmark, K. (2015), 'Hur påverkar vinstmotivet och konsolideringen av skolmarknaden skolans verksamhet?', in Johan Eklund (ed.), Swedish Economic Forum Report 2015: Vinster, välfärd och entreprenörskap, Stockholm: Entreprenörskapsforum, pp. 71-87.

Eggertsson, T. (2005), Imperfect Institutions: Possibilities and Limits of Reform, Ann Arbor, Mich: University of Michigan Press.

Figlio, D. and Lucas, M. (2004), 'Do High Grading Standards Affect Student Performance?', Journal of Public Economics, 88(9-10): 1815-1834.

Frank, R. H. (2012), The Darwin Economy: Liberty, Competition, and the Common Good, Princeton, NJ: Princeton University Press.

Fredriksson, P. and Vlachos, J. (2011), Reformer och resultat: Kommer regeringens utbildningsreformer att ha någon betydelse?, Stockholm: Finanspolitiska rådet.

Friedman, M. (1955), 'The Role of Government in Education', in Robert A Solo (ed.), Economics and the Public Interest, New Brunswick, NJ: Rutgers University Press, pp. $123-144$.

Friedman, M. (1962/2002), Capitalism and Freedom: Fortieth Anniversary Edition, Chicago, IL: University of Chicago Press.

Friedman, M. and Friedman, R. (1980), Free to Choose: A Personal Statement, London: Pelican.

Gibton, D. (2016), Researching Education Policy, Public Policy, and Policymakers: Qualitative Methods and Ethical Issues, London and New York: Routledge.

Government bill. (1990/91:18), Om ansvaret för skolan, Stockholm.

Government bill. (1990/91:115), Om vissa skollagsfrågor m.m., Stockholm. 
Government bill. (1991/92:95), Om valfrihet och fristående skolor, Stockholm.

Government bill. (1992/93:230), Valfrihet $i$ skolan, Stockholm.

Government bill. (1995/96:200), Fristående skolor m.m., Stockholm.

Gustafsson, L. R. (2012), What Did You Learn in School Today? How Ideas Mattered for Policy Changes in Danish and Swedish Schools 1990-2011, Aarhus: Politica.

Haldén, E. (1997), Ett centralt ämbetsverk i omvandling - från Skolöverstyrelsen till Skolverket, Stockholm: Stockholm Center for Organizational Research, SCORE.

Hanushek, E. A., Peterson, P. E. and Woessman, L. (2012), Achievement Growth: International and U.S. State Trends in Student Performance, Cambridge, MA: Harvard Program on Education Policy and Governance.

Heckman, J. J. and Rubenstein, Y. (2001), 'The Importance of Noncognitive Skills: Lessons from the GED Testing Program', The American Economic Review, 91(2): 145-149.

Heller Sahlgren, G. (2015), Real Finnish Lessons: The True Story of an Education Superpower, London: Centre for Policy Studies.

Hellman, J. (1993), 'En oåterkallelig skolreform', Svenska Dagbladet, 8 June.

Henrekson, M. (2017), 'Skolans problem: fallande kunskaper och flykten från läraryrket', in Magnus Henrekson (ed.), Kunskapssynen och pedagogiken: varför skolan slutade leverera och hur det kan åtgärdas, Stockholm: Dialogos, pp. 26-64.

Henrekson, M. and Jävervall, S. (2016), Det svenska kunskapsfallet: vad vet vi?, Stockholm: Royal Swedish Academy of Engineering Sciences.

Hodgson, G. M. (2006), 'What Are Institutions?', Journal of Economic Issues, 40(1): 1-25.

Hodgson, G. M. (2013), From Pleasure Machines to Moral Communities: An Evolutionary Economics without Homo Economicus, Chicago, IL: University of Chicago Press.

Holmlund, H., Häggblom, J., Lindahl, E., Martinson, S., Sjögren, A., Vikman, U. and Öckert, B. (2014), Decentralisering och fristående skolor: resultat och likvärdighet $i$ svensk skola, Stockholm: IFAU.

Hörnqvist, B. (2012), Utveckling av ungas kompetenser för framtiden: en översikt över internationella initiativ, Stockholm: Swedish National Agency for Education.

Jordahl, H. and Öhrvall, R. (2013), 'Nationella reformer och lokala initiativ', in Henrik Jordahl (ed.), Välfärdstjänster i privat regi: framväxt och drivkrafter, Stockholm: SNS förlag, pp. 33-87.

Kasper, W., Streit, M. E. and Boettke, P. J. (2013), Institutional Economics: Property, Competition, Policies, Cheltenham and Northampton, MA: Edward Elgar.

Komatsu, H. and Rappleye, J. (2017), 'Did the Shift to Computer-Based Testing in PISA 2015 Affect Reading Scores? A View from East Asia', Compare: A Journal of Comparative and International Education, 47(4): 616-623.

Kornhall, P. (2013), Barnexperimentet: svensk skola i fritt fall, Stockholm: Leopard förlag.

Kreiner, S. and Christensen, K. B. (2014), 'Analyses of Model Fit and Robustness. A New Look at the Pisa Scaling Model Underlying Ranking of Countries According to Reading Literacy', Psychometrika, 79(2): 210-231.

Le Grand, J. and Bartlett, W. (1993), 'The Theory of Quasi Markets', in Julian Le Grand \& Will Bartlett (eds.), Quasi Markets and Social Policy, London: Palgrave Macmillan, pp. 1334.

Levitt, S. D. and Jacob, B. A. (2003), 'Rotten Apples: An Investigation of the Prevalence and Predictors of Teacher Cheating', Quarterly Journal of Economics, 118(3): 843-877.

Lewin, L. (2014), Staten får inte abdikera - om kommunaliseringen av den svenska skolan. Betänkande av Utredningen om skolans kommunalisering. SOU 2014:5, Stockholm: Fritzes.

Lindbeck, A. (1995), 'Hazardous Welfare-State Dynamics', American Economic Review, 85(2): 9-15.

Löfbom, E. and Sonnerby, P. (2015), Utbildning för framtidens arbetsmarknad: Bilaga 5 till Långtidsutredningen 2015. SOU 1015:90, Stockholm: Elanders Sverige AB.

Mullis, I. V. S., Martin, M. O., Foy, P. and Arora, A. (2012), TIMSS 2011 International Results in Mathematics, Chestnut Hill, MA: TIMSS \& PIRLS International Study Center, Lynch School of Education, Boston College. 
Murray, C. (2008), Real Education: Four Simple Truths for Bringing America's Schools Back to Reality, New York, NY: Three Rivers Press.

Nooteboom, B. (2014), How Markets Work and Fail, and What to Make of Them, Cheltenham and Northampton, MA: Edward Elgar.

North, D. C. (1990), Institutions, Institutional Change, and Economic Performance, Cambridge: Cambridge University Press.

OECD. (2013a), OECD Skills Outlook 2013: First Results from the Survey of Adult Skills, Paris: OECD Publishing.

OECD. (2013b), PISA 2012 Results: What Students Know and Can Do: Student Performance in Mathematics, Reading and Science (Volume I), Paris: OECD Publishing.

OECD. (2015), Improving Schools in Sweden: An OECD Perspective, Paris: OECD Publishing.

Ostrom, E. (1990), Governing the Commons: The Evolution of Institutions for Collective Action, Cambridge: Cambridge University Press.

Posner, R. (2009), A Failure of Capitalism: The Crisis of '08 and the Descent into Depression, Cambridge, MA: Harvard University Press.

Rajan, R. (2010), Fault Lines: How Hidden Fractures Still Threaten the World Economy, Princeton, NJ: Princeton University Press.

Ratnapala, S. (2006), 'Moral Capital and Commercial Society', in Robert Higgs \& Carl P Close (eds.), The Challenge of Liberty: Classical Liberalism Today, Oakland, CA: The Independent Institute, pp. 97-119.

Reinfeldt, F. (2015), Halvvägs, Stockholm: Alberts Bonniers Förlag.

Ringarp, J. (2011), Professionens problematik: lärarkårens kommunalisering och välfärdsstatens förvandling, Stockholm: Makadam.

Sandel, M. J. (2012), What Money Can't Buy: The Moral Limits of Markets, New York, NY: Farrar, Straus and Giroux.

Sandström, M. and Bergström, F. (2005), 'School Vouchers in Practice: Competition Will Not Hurt You', Journal of Public Economics, 89(2-3): 351-380.

Svenska Dagbladet. (1993a), 'Makten till föräldrarna', 3 June.

Svenska Dagbladet. (1993b), 'Valfrihet skolministerns ledstjärna', 8 April.

Svenska Dagbladet. (1994a), 'Bör bra skolor ge höga betyg?', 18 January.

Svenska Dagbladet. (1994b), 'Profilering även i kommunal skola', 24 January.

Svenska Dagbladet. (2009), 'Elever på friskolor får bättre datorer', 17 April. Available at: http://www.svd.se/elever-pa-friskolor-far-battre-datorer.

Svenskt Kvalitetsindex. (2015), Samhällsservice 2015, Stockholm: Svenskt Kvalitetsindex.

Swedish law. (2010:800), Skollag, Stockholm.

Swedish National Agency for Education. (1994), Läroplan för det obligatoriska skolväsendet, förekoleklassen och fritidshemmet Lpo 94, Stockholm: Skolverket.

Swedish National Agency for Education. (1996), Grundskola för bildning, Stockholm: Skolverket.

Swedish National Agency for Education. (2005), Nationella prov i gymnasieskolan - ett stöd för likvärdig betygsättning, Stockholm: Skolverket.

Swedish National Agency for Education. (2014), 'Varför deltar Sverige i internationella studier?'. Available at: http://www.skolverket.se/statistik-ochutvardering/internationella-studier/varfor-deltar-sverige-i-internationella-studier1.202314.

Tyrefors Hinnerich, B. and Vlachos, J. (2013), 'Systematiska skillnader mellan interna och externa bedömare av nationella prov - en uppföljningsrapport', Olikheterna är för stora. Omrättning av nationella prov i grundskolan och gymnasieskolan, 2013:

Resultatbilaga, Stockholm: Skolinspektionen, pp. 86-138.

Tyrefors Hinnerich, B. and Vlachos, J. (2016), 'The Impact of Upper-Secondary Voucher School Attendance on Student Achievement: Swedish Evidence using External and Internal Evaluations', IFN Working Paper No. 1127.

Vlachos, J. (2010), Betygets värde: En analys av hur konkurrens påverkar betygssättningen vid svenska skolor, Stockholm: Konkurrensverket. 
Vlachos, J. (2012), 'Är vinst och konkurrens en bra modell för skolan?', Ekonomisk Debatt, 40(4): 16-30.

Wikström, C. and Wikström, M. (2005), 'Grade Inflation and School Competition: An Empirical Analysis Based on the Swedish Upper Secondary Schools', Economics of Education Review, 24(3): 309-322.

\section{NOTES}

${ }^{1}$ The reform was expanded from primary education to include secondary education in 1993 (Government bill, 1992/93:230).

${ }^{2}$ The aspect of cost is not discussed in this article.

${ }^{3}$ See Betts and Grogger (2003), Figlio and Lucas (2004), and Bonnesrönning (2004b) for studies demonstrating that pupils learn less when grading is not stringent.

${ }^{4}$ In 2013, 98 percent of pupils entered secondary education immediately after finishing year 9 of mandatory primary education (see the Swedish National Agency for Education: www.skolverket.se).

${ }^{5}$ The share of pupils who went to independent schools in 1992 was 1 percent in primary education and 1,7 per cent in secondary education (Jordahl and Öhrvall, 2013).

${ }^{6}$ According to Anders Hultin (telephone interview, 11 February, 2014), political adviser in the centre-right government 1991-1994, many in the Department of Education believed that the school choice reform was only "symbolic" and would have a marginal effect in practice.

${ }^{7}$ The Programme for International Student Assessment (PISA) is a worldwide study by the Organization for Economic Co-operation and Development (OECD). In Sweden, the test is taken in the year the pupils turn sixteen.

${ }^{8}$ See, for example, Murray (2008).

${ }^{9}$ The Trends in International Mathematics and Science Study (TIMSS) is a worldwide study by the International Association for the Evaluation of Educational Achievement (IEA). TIMSS 2015, released on 29 November 2016, showed improvement in both mathematics and science. However, Swedish pupils fare below the EU/OECD average in mathematics and Swedish $8^{\text {th }}$ graders are still outperformed by American pupils. The exception is the highest percentile of pupils, which is now on the same level as the corresponding U.S. percentile (Henrekson, 2017). In science, Swedish pupils are still trailing behind the results of TIMSS 1995, in which Sweden was ranked as the top science nation.

${ }^{10}$ PISA 2015, released on 6 December 2016, showed improvement in all three subjects. However, a shift to computer-based testing - which seems to have disproportionately benefitted Swedish pupils-makes comparisons with previous results precarious (see Komatsu and Rappleye, 2017).

${ }^{11}$ PISA is not an uncontroversial assessment, particularly with respect to its ranking of countries (Kreiner and Christensen, 2014). However, other international assessments as well as various domestic tests of knowledge among Swedish pupils show the same declining trend (Henrekson and Jävervall, 2016).

${ }^{12}$ In this article grade inflation is defined as the difference between teacher-assigned grades and the results in international assessments. 
${ }^{13}$ The Programme for the International Assessment of Adult Competencies (PIACC) is an international survey by the OECD.

${ }^{14}$ See, for example, Aftonbladet (2007), "Schools fight over secondary school pupils", and Svenska Dagbladet (2009), "Pupils in independent schools have superior computers".

15 Wikström \& Wikström (2005) is interesting because these authors study school competition at an early point in time when the independent school sector was still in its infancy. Thus, it is not surprising that they find "small and selective" effects of school competition on grade inflation (p. 317). However, it is noteworthy that as early as 1997, they found that "independent schools seriously engage in grade inflation" and that "students in independent schools appear to fare much better under decentralized grade setting than in the public schools" (p. 317). This suggests that the incentive for parents and pupils to choose an independent school to receive good grades and for public schools to gradually adapt has been strong since the late 1990s, at least in secondary education.

${ }^{16}$ Vlachos (2010) studies grade inflation by looking at the difference between grades and performance on Swedish standardized tests, between grades in practical-aesthetic subjects and grades in subjects with standardized tests, and between grades in primary and secondary education. The relationship between grade inflation and school competition is also discussed in Fredriksson and Vlachos (2011).

${ }^{17}$ The result was supported by Holmlund et al. (2014) in a study using a similar methodology (grades and Swedish standardized tests). Although the effect was small, the authors found that independent schools are more generous in grade setting than public schools and that grade inflation has been more prevalent in Swedish municipalities with a high degree of school competition measured by the Herfindahl index.

${ }^{18}$ Böhlmark and Lindahl (2015) follow the same approach as Vlachos (2010) and find no effect. However, since there were two different grading systems in operation during their period of study - one cohort-referenced and one criterion-referenced - the results should be interpreted with caution.

${ }^{19}$ Entrance exams to universities are almost invariably never used in Sweden.

${ }^{20}$ In a study of Chicago public schools, Levitt and Jacob (2003, p. 843) found that "[teacher] cheating appears to respond strongly to relatively minor changes in incentives." This is also suggested by Borcan, Lindahl and Mitrut (2014, p. 32), whose study demonstrated that a wage loss for Romanian public sector employees, including teachers, "induced better exam outcomes in public than in private schools." Using evidence from a natural experiment in Italy, Bertoni, Brunello and Rocco (2013) found that the presence of an external examiner reduced cheating by teachers and students on standardized educational tests.

${ }^{21}$ See section 2 of this article. 
Figure 1. Merit rating and PISA Score points, 1998-2012

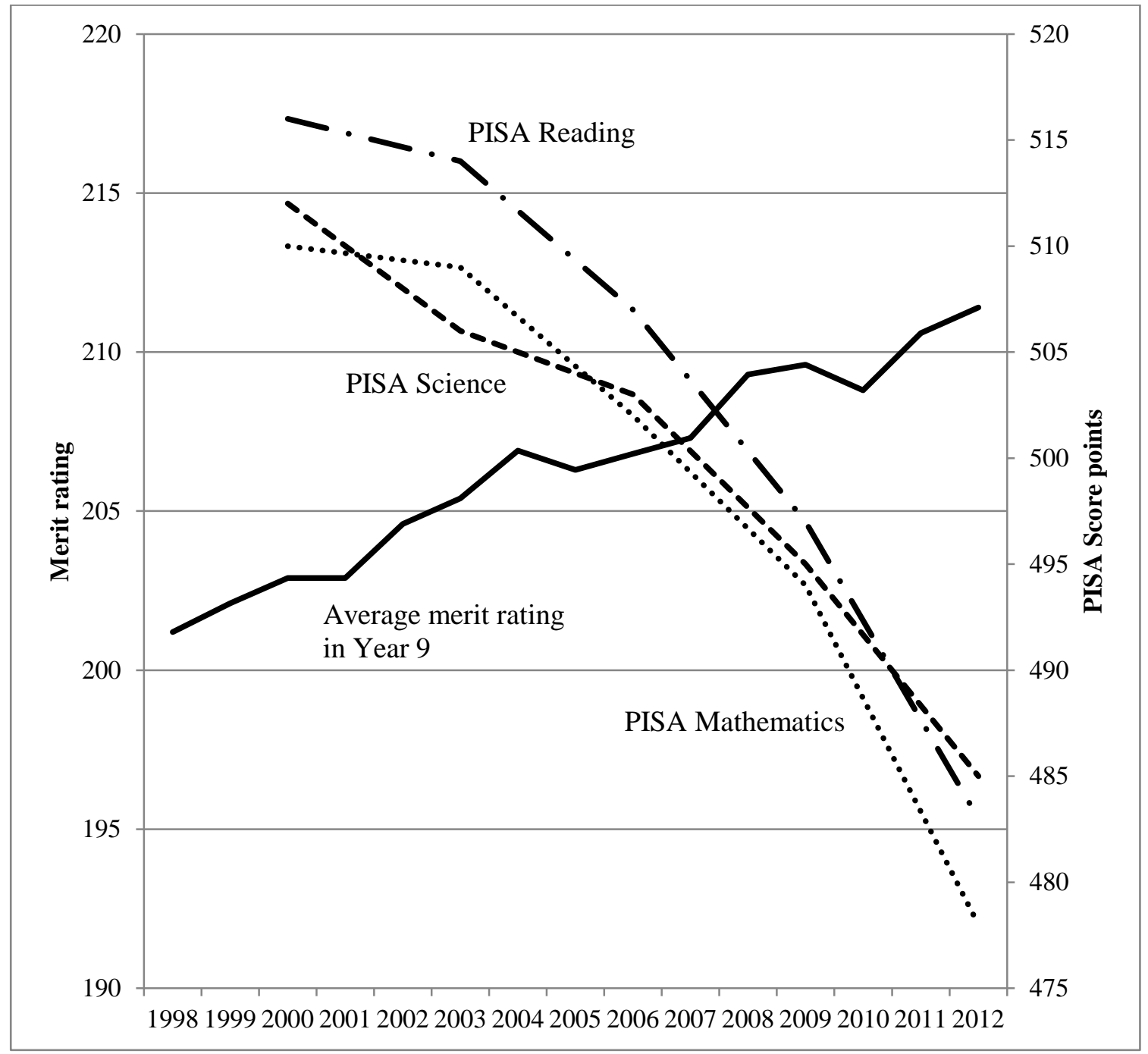

Source: OECD (2015), Improving Schools in Sweden: An OECD Perspective, http://www.oecd.org/edu/school/improving-schools-in-sweden-an-oecd-perspective.htm - reproduced by permission. The development of the average merit rating in year 9, shown on the left axis, is contrasted with PISA assessment data, shown on the right axis. 
Table 1. US advantage in TIMSS 2011 International Results in Mathematics

\begin{tabular}{|c|c|c|c|c|c|c|c|}
\hline \multicolumn{8}{|c|}{ TIMSS Fourth Grade } \\
\hline & $\begin{array}{c}5^{\text {th }} \\
\text { Percentile }\end{array}$ & $\begin{array}{c}10^{\text {th }} \\
\text { Percentile }\end{array}$ & $\begin{array}{c}25^{\text {th }} \\
\text { Percentile }\end{array}$ & $\begin{array}{c}50^{\text {th }} \\
\text { Percentile }\end{array}$ & $\begin{array}{c}75^{\text {th }} \\
\text { Percentile }\end{array}$ & $\begin{array}{c}90^{\text {th }} \\
\text { Percentile }\end{array}$ & $\begin{array}{c}95^{\text {th }} \\
\text { Percentile }\end{array}$ \\
\hline Sweden & 388 & 416 & 462 & 507 & 549 & 587 & 610 \\
\hline USA & 410 & 440 & 492 & 544 & 593 & 635 & 660 \\
\hline $\begin{array}{c}\text { US } \\
\text { advantage } \\
\text { compared } \\
\text { to Sweden }\end{array}$ & 22 & 24 & 30 & 37 & 44 & 48 & 50 \\
\hline \multicolumn{8}{|c|}{ TIMSS Eighth Grade } \\
\hline & $\begin{array}{c}5^{\text {th }} \\
\text { Percentile }\end{array}$ & $\begin{array}{c}10^{\text {th }} \\
\text { Percentile }\end{array}$ & $\begin{array}{c}25^{\text {th }} \\
\text { Percentile }\end{array}$ & $\begin{array}{c}50^{\text {th }} \\
\text { Percentile }\end{array}$ & $\begin{array}{c}75^{\text {th }} \\
\text { Percentile }\end{array}$ & $\begin{array}{c}90^{\text {th }} \\
\text { Percentile }\end{array}$ & $\begin{array}{c}95^{\text {th }} \\
\text { Percentile }\end{array}$ \\
\hline Sweden & 368 & 395 & 440 & 487 & 532 & 569 & 590 \\
\hline USA & 381 & 409 & 457 & 511 & 562 & 607 & 635 \\
\hline $\begin{array}{c}\text { US } \\
\text { advantage } \\
\text { compared } \\
\text { to Sweden }\end{array}$ & 13 & 14 & 17 & 24 & 30 & 38 & 45 \\
\hline
\end{tabular}

Source: Mullis, et al. (2012), TIMSS 2011 International Results in Mathematics. Data are from appendix G. Note that US students consistently have an advantage over Swedish students. Even the weakest American student is comperatively stronger than the weakest Swedish student. 